\title{
Serial 3 orthogonal lead electrocardiographic abnormalities after pulmonary embolism Computer assisted study
}

\author{
F. Dunn, A. Henderson, P. W. Macfarlane, F. Moran, and T. D. V. Lawrie \\ From University Department of Medical Cardiology, Royal Infirmary, Glasgow; and Centre for Respiratory \\ Investigation, Royal Infirmary, Glasgow
}

\begin{abstract}
The 3 orthogonal lead electrocardiogram has been evaluated with computer assisted interpretation in 20 patients with acute pulmonary embolism confirmed by pulmcnary angiography. Initial 3-lead electrccardiographic abnormalities were found to be at least as helpful as the 12-lead electrocardiogram in supporting the clinical diagnosis. In addition, however, sequential changes in both the maximum $Q R S$ and $T$ vector orientations in frontal and transverse planes were more often apparent than any sequential changes in the 12-lead electrocardiogram. While no specific 3 lead electrocardiographic criterion for pulmonary embolism could be determined, this technique was more helpful than conventional methods in following serial electrocardiographic changes in patients with this condition.
\end{abstract}

The recent availability of pulmonary angiography has facilitated a more critical appraisal of the 12 lead electrocardiographic appearances in acute pulmonary embolism than has hitherto been possible (Stein et al., 1975). As far as is known, there have, however, been no studies to evaluate serial 3 orthogonal lead electrocardiographic abnormalities in patients with acute pulmonary embolism proven angiographically. With the recent availability of a routinely used computer programme for storing orthogonal lead data to enable comment on day-today electrocardiographic changes to be made (Macfarlane, Cawood, and Lawrie, 1975), it was decided to undertake a study of 3 orthogonal lead (and corresponding 12 lead) electrocardiograms in order to determine whether or not diagnostic criteria for a positive electrocardiographic change could be incorporated into the routinely used programme.

Subjects and methods

Twenty patients (12 male and 8 female-mean age $52 \pm 13$ ) were included in the study. In all cases a diagnosis of acute pulmonary embolism was suspected on clinical grounds and confirmed by pulmonary angiography. Routine clinical investigations were performed in all patients including chest Received 3 November 1975. $x$-ray, serial enzyme studies, full blood count and ESR. Patients were divided into two groups for purposes of analysis. Group 1 consisted of 14 patients with no previous history of cardiac or respiratory disease. Group 2 consisted of 6 patients who had a significant cardiac or respiratory history which per se had led to the development of an abnormal electrocardiogram. The details of age, sex, duration of symptoms before presentation, together with the underlying diagnosis are shown for groups 1 and 2 in Tables 1 and 2, respectively.

Pulmonary angiography was performed in all cases. A $7 \times 125$ Gensini catheter was passed via a right medial cubital vein into right atrium, right ventricle, and then into the main pulmonary artery. Pressure measurements were taken in these three sites. The catheter was then left in the main pulmonary artery and 45 to $55 \mathrm{ml}$ (dose depending on body weight) angiografin were then injected using a Girdlund H-P injector. The angiogram was recorded on $35 \times 35 \mathrm{~cm}$ film using an Elema Schonander rapid film changer in conjunction with a high speed fine focus tube. Films were exposed at a rate of 4 per second for 4 seconds and thereafter 1 per second for 9 seconds, allowing dynamic features of the angiogram to be assessed. All patients met one or more of the following major criteria for pulmonary embolism. 
TABLE 1 Patients with no history of cardiac or respiratory disease (group 1)

\begin{tabular}{lllll}
\hline $\begin{array}{l}\text { Case } \\
\text { No. }\end{array}$ & Age & Sex & $\begin{array}{l}\text { Duration of symptoms } \\
\text { before presentation }(\mathrm{hr})\end{array}$ & Underlying diagnosis \\
\hline 1 & 48 & $\mathrm{~F}$ & $<24$ & Duodenal ulcer: post vagotomy \\
2 & 61 & $\mathrm{M}$ & $<24$ & Appendicitis: post apppendicectomy \\
3 & 77 & $\mathrm{~F}$ & $<24$ & Acute pancreatitis \\
$\mathbf{4}$ & 53 & $\mathrm{M}$ & $<48$ & Thrombophlebitis \\
5 & 39 & $\mathrm{M}$ & $<48$ & Varicose veins: post ligation \\
6 & 47 & $\mathrm{~F}$ & $<48$ & Nil \\
7 & 62 & $\mathrm{M}$ & $<48$ & Deep venous thrombosis \\
8 & 63 & $\mathrm{M}$ & $<24$ & Duodenal ulcer: post vagotomy \\
9 & 60 & $\mathrm{M}$ & $<24$ & Varicose veins: post ligation \\
10 & 48 & $\mathrm{M}$ & $<24$ & Varicose veins: post ligation \\
11 & 38 & $\mathrm{~F}$ & $<48$ & Fibroids: post hysterectomy \\
12 & $\mathbf{4 2}$ & $\mathrm{F}$ & $<24$ & Obesity \\
13 & 25 & $\mathrm{M}$ & $<24$ & Carcinoma of oesophagus \\
14 & $\mathbf{7 1}$ & $\mathrm{F}$ & $<24$ & Deep venous thrombosis \\
\hline
\end{tabular}

TABLB 2 Patients with positive history of previous cardiac or respiratory disease (group 2)

\begin{tabular}{|c|c|c|c|c|}
\hline $\begin{array}{l}\text { Case } \\
\text { No. }\end{array}$ & Age & Sex & $\begin{array}{l}\text { Duration of symptoms } \\
\text { before presentation }(\mathrm{hr})\end{array}$ & Underlying diagnosis \\
\hline $\begin{array}{l}15 \\
16 \\
17 \\
18 \\
19 \\
20\end{array}$ & $\begin{array}{l}42 \\
48 \\
66 \\
57 \\
34 \\
62\end{array}$ & $\begin{array}{l}\mathbf{M} \\
\mathbf{M} \\
\mathbf{M} \\
\mathbf{M} \\
\mathbf{F} \\
\mathbf{F}\end{array}$ & $\begin{array}{l}<24 \\
<24 \\
<24 \\
<48 \\
<24 \\
<48\end{array}$ & $\begin{array}{l}\text { Atrial fibrillation } \\
\text { Previous myocardial infarction } \\
\text { Previous myocardial infarction } \\
\text { Angina } \\
\text { Rheumatic heart disease } \\
\text { Chondroma } \\
\text { right lung; previous resection } \\
\text { right middle and lower lobe }\end{array}$ \\
\hline
\end{tabular}

(1) Cut-off vessels of large or medium calibre.

(2) Filling defects appearing consistently throughout the arterial phase of the injection.

(3) Vessel loss not related to bullous emphysema. Patients were subsequently grouped into three categories as follows according to the pulmonary arterial pressure noted during angiography:

(a) Normal: systolic pulmonary artery pressure $<30 \mathrm{mmHg}(4 \mathrm{kPa})$.

(b) Moderate pulmonary hypertension: systolic pulmonary artery pressure 30 to $45 \mathrm{mmHg}$ (4 to $6 \mathrm{kPa})$.

(c) Severe pulmonary hypertension: systolic pulmonary artery pressure $>45 \mathrm{mmHg}(6 \mathrm{kPa})$.

The orthogonal lead electrocardiograms (anterolateral lead $X$, inferior lead $Y$, and anteroseptal lead $\mathrm{Z}$ cf $\mathrm{I}, \mathrm{aVF}, \mathrm{V} 2$ ) were recorded on each patient using the modified axial lead system (Macfarlane, 1969). Tape recordings were made using a 4channel FM magnetic tape recorder and the eletrocardiograms were replayed to a PDP8E computer for analysis using a programme which has been described in detail previously (Macfarlane and Lawrie, 1974). Included in the computer print-out were projections of the maximum QRS and $T$ vectors onto the frontal and transverse planes denoted $Q R S_{F}, Q R S_{T}, T_{F}$, and $T_{T}$, respectively, together with corresponding vector magnitudes.

The following relevant criteria were used for the 3 orthogonal lead electrocardiogram. These have been extracted from the detailed list of diagnostic criteria to be published elsewhere (Macfarlane and Lawrie, 1977) and are presented in simplified form.

(1) RAD: QRS $F>65^{\circ}$.

(2) LAD: $270<$ QRS $_{F}<360^{\circ}$.

(3) Clockwise cardiac rotation: $180<\mathrm{QRS}_{\mathrm{T}}<360^{\circ}$ and negative $Q R S \times$ area.

(4) LVH: Max QRS vector amplitude $>2.5 \mathrm{mV}$ or $\mathrm{R} x>2 \cdot 1 \mathrm{mV}$ or $\mathrm{S} z>1.2 \mathrm{mV}$.

(5) $\mathrm{RVH}:(\mathbf{R} / \mathrm{S}) \mathrm{z}>3$ or $\mathbf{R}_{\mathrm{z}}>0.85 \mathrm{mV}$ or $\left(\mathrm{S}_{\mathrm{x}}>0.55 \mathrm{mV}\right.$ and $\left.\mathrm{S} \mathrm{x}>\mathrm{R} \mathrm{x}\right)$.

(6) Myocardial infarction:

(a) Inferior: $(\mathrm{Q} / \mathrm{R})_{\mathrm{y}}>1 / 3$ and $\mathrm{Q}_{\mathrm{y}}>0.03 \mathrm{~s}$.

(b) Anteroseptal: $\mathrm{Q}_{\mathrm{z}}>0.02 \mathrm{~s}$ and $\mathrm{Qz}>0.1 \mathrm{mV}$ or $\left(\mathrm{R}_{\mathrm{z}}<0.10 \mathrm{mV}\right.$ and $(\mathrm{R} / \mathrm{S}) \mathrm{z}<1 / 10$ and $180^{\circ}<0.03 \mathrm{sec} \mathrm{QRS}{ }_{\mathrm{T}}<330^{\circ}$ ).

(7) $\mathrm{T}$ wave abnormalities: $\mathrm{T}_{\mathrm{x}}<0.05 \mathrm{mV}$ or $\mathrm{T}_{\mathrm{y}}<0.05 \mathrm{mV}$ or $\mathrm{T}_{\mathrm{z}}<-0.05 \mathrm{mV}$. 
(8) ST abnormalities: Visible ST junctional depression and ST segment flat or downward sloping in any lead.

\section{Sequential changes}

(9) $T$ vector: A day-to-day change in $T_{T}$ or $T_{F}$ of more than $30^{\circ}$.

(10) QRS vector: $A$ day to day change in $Q R S_{F}>$ $20^{\circ}$ or in QRS ${ }_{\mathrm{T}}>25^{\circ}$.

The normal limits of day-to-day change have been discussed elsewhere (Cawood et al., 1974). If $T$ wave inversion were found to be present in the anteroseptal lead with or without $T$ wave abnormalities in the inferior leads, and if the clinical diagnosis were pulmonary embolism, the computer programme would report $T$ wave changes 'consistent with the clinical diagnosis of pulmonary embolism'.

Twelve lead electrocardiograms were also recorded on each patient using a Siemens direct writing single channel machine. The paper speed was $25 \mathrm{~mm} / \mathrm{s}$ and the calibration was adjusted such that a $10 \mathrm{~mm}$ deflection was equal to $1 \mathrm{mV}$. The 12 lead electrocardiogram tracing was recorded at the same time as the 3 lead electrocardiogram. The following diagnostic criteria were used in con- junction with interpretation of the 12 lead electrocardiogram by two of the authors. The QRS axis in the frontal plane was determined from Tables (Goldman, 1970).

(1) RAD: Frontal QRS axis $>110^{\circ}$.

(2) LAD: Frontal QRS axis $<-30^{\circ}$.

(3) Clockwise cardiac rotation: transition line at V5 with $S_{\mathrm{V}_{6}}$ present.

(4) $\mathrm{RVH}$ : $(\mathrm{R} / \mathrm{S}) \mathrm{v}_{1}>1$ and $\mathrm{R}_{\mathrm{v}}>0.7 \mathrm{mV}$.

(5) $\mathrm{S}_{1} \mathrm{Q}_{3} \quad \mathrm{~T}_{3}: \mathrm{S}_{\mathrm{I}}>0.15 \mathrm{mV}$ and $\mathrm{Q}_{\mathrm{III}}>0.15 \mathrm{mV}$ and $\mathrm{T}_{\mathrm{III}}<0 \mathrm{mV}$.

(6) $\mathrm{LVH}$ : $S_{\mathrm{v}_{1}}+\mathrm{R}_{\mathrm{v}_{5}}>3.5 \mathrm{mV}$ or $\mathrm{R}_{\mathrm{avL}}>1.1 \mathrm{mV}$ or $\mathbf{R}_{\mathbf{a}} \mathbf{F}>1.5 \mathrm{mV}$.

(7) Myocardial infarction:

(a) Inferior: $Q>0.035 \mathrm{~s}$ and $\mathrm{Q}>1 / 4 \mathrm{R}$ in any two of II, III, aVF.

(b) Anteroseptal: $Q>0.20 \mathrm{mV}$ in any two leads V2 to V4 or $\mathrm{R}<0.10 \mathrm{mV}$ in any two leads V2 to V4.

(8) $\mathrm{T}$ wave abnormalities: flat or inverted $\mathrm{T}$ waves in relevant leads.

(9) ST abnormalities: visible ST junctional depression and ST segment flat or downward sloping in relevant leads.

Sequential $T$ wave changes were diagnosed from 12 lead electrocardiograms in a somewhat subjective

TABLE 3 Initial 12 and 3 lead electrocardiogram in group 1

\begin{tabular}{|c|c|c|c|c|}
\hline $\begin{array}{l}\text { Case } \\
\text { No. }\end{array}$ & Lead & Electrocardiographic changes & $\begin{array}{l}\text { Pulmona } \\
\text { mmHg }\end{array}$ & $\begin{array}{l}y \text { pressure } \\
\mathrm{kPa}\end{array}$ \\
\hline 1 & $\left.\begin{array}{r}12 \\
3\end{array}\right\}$ & Normal & $35 / 11$ & $4.7 / 1 \cdot 5$ \\
\hline 2 & 12 & $\begin{array}{l}S_{1} Q_{3} T_{3} \\
Q \text { wave in } Y \text { lead; LAD }\end{array}$ & $76 / 28$ & $10 \cdot 1 / 3 \cdot 7$ \\
\hline 3 & $\left.\begin{array}{r}12 \\
3\end{array}\right\}$ & ST-T changes of inferior ischaemia & $50 / 17$ & $6 \cdot 7 / 2 \cdot 3$ \\
\hline 4 & $\left.\begin{array}{r}12 \\
3\end{array}\right\}$ & $\begin{array}{l}\text { ST-T changes of anteroseptal and lateral } \\
\text { ischaemia }\end{array}$ & $43 / 20$ & $5 \cdot 7 / 3 \cdot 7$ \\
\hline 5 & 12 & $\begin{array}{l}\text { ST-T changes of inferior ischaemia } \\
\text { ST-T changes of inferior ischaemia; LAD }\end{array}$ & $39 / 11$ & $5 \cdot 2 / 1 \cdot 5$ \\
\hline 6 & $\left.\begin{array}{r}12 \\
3\end{array}\right\}$ & Normal & $28 / 18$ & $3 \cdot 7 / 2 \cdot 4$ \\
\hline 7 & $\left.\begin{array}{r}12 \\
3\end{array}\right\}$ & Left ventricular hypertrophy & $56 / 14$ & $7 \cdot 5 / 1 \cdot 9$ \\
\hline 8 & $\left.\begin{array}{r}12 \\
3\end{array}\right\}$ & Normal & $37 / 12$ & $4 \cdot 9 / 1 \cdot 6$ \\
\hline 9 & $\begin{array}{c}12 \\
3\end{array}$ & $\begin{array}{l}\text { Normal } \\
\text { LAD }\end{array}$ & $26 / 13$ & $3 \cdot 5 / 1 \cdot 7$ \\
\hline 10 & $\left.\begin{array}{r}12 \\
3\end{array}\right\}$ & $\mathrm{T}$ wave inversion $\mathrm{V} 1-\mathrm{V} 3$ and in $\mathrm{Z}$ lead & $27 / 6$ & $3 \cdot 6 / 0 \cdot 8$ \\
\hline 11 & $\left.\begin{array}{r}12 \\
3\end{array}\right\}$ & $\mathbf{T}$ wave inversion in lateral leads & $27 / 9$ & $3 \cdot 6 / 1 \cdot 2$ \\
\hline 12 & $\left.\begin{array}{r}12\} \\
3\end{array}\right\}$ & Normal & $25 / 15$ & $3 \cdot 3 / 2$ \\
\hline 13 & $\begin{array}{c}12 \\
3\end{array}$ & $\begin{array}{l}S_{1} Q_{3} T_{3} C C R T \text { wave inversion V1-V3 } \\
T \text { wave inversion } Z \text { lead, CCR, RAD }\end{array}$ & $50 / 15$ & $6 \cdot 7 / 2$ \\
\hline 14 & $\begin{array}{r}12 \\
3\end{array}$ & $\begin{array}{l}S_{1} Q_{3} T_{8} C C R T \text { wave inversion V1-V3 } \\
T \text { wave inversion } Z \text { lead, RAD, CCR }\end{array}$ & $52 / 14$ & $6.9 / 1.9$ \\
\hline
\end{tabular}

LAD, left axis deviation; RAD, right axis deviation; CCR, clockwise cardiac rotation. 
manner by the two reviewers on the basis of the appearance of fresh $T$ wave inversion or increase in inverted $T$ wave amplitudes. Sequential $Q R S$ axis changes could not be reported as no known criteria were available.

Three and 12 lead electrocardiograms were recorded from almost all patients on at least 3 occasions, including the time of presentation, which was always less than 48 hours from the onset of symptoms, and the day of pulmonary angiography.

\section{Group 1}

\section{Results}

The main features of the initial 3 and 12 lead electrocardiograms together with pulmonary artery pressure are shown for each patient in Table 3. Three and 12 lead findings were the same in 9 patients while all patients were in sinus rhythm. Table 4 summarizes the frequency of selected electrocardiographic measurements.

Table 5 presents the sequential electrocardiographic abnormalities detected in group 1 patients. Sequential changes in either the QRS or $T$ vectors were present in 8 patients according to 3 lead diagnostic criteria while sequential $T$ wave changes in the 12 lead electrocardiograms were noted in 6 patients. QRS vector angles in the frontal and transverse planes are shown where an abnormal shift has occurred or where the vector has moved from a normal to an abnormal orientation.

Pulmonary artery pressure was normal in 5 patients in this group, moderately raised in 4 patients, and severely raised in 5 . All three patients with $S_{1} Q_{3} T_{3}$ had severe pulmonary hypertension as had the two patients with marked $\mathrm{QRS}_{F}$ vector shifts detected by the 3 lead electrocardiogram.

\section{Group 2}

Three and 12 lead electrocardiogram results in group 2 patients are summarized in Table 6 . There was no difference between initial 3 and 12 lead reports, but five patients subsequently showed

TABLE 4 Summary of 3 and 12 lead appearances, group 1

\begin{tabular}{lll}
\hline & 3-lead & 12-lead \\
\hline Sinus tachycardia & 5 & 5 \\
Atrial ectopics & 2 & 2 \\
$\mathrm{~S}_{1} \mathrm{Q}_{3} \mathrm{~T}_{3}$ & 0 & 3 \\
$\mathrm{~T}$ wave inverted & & \\
$\quad$ anteroseptal leads & 3 & 3 \\
Left axis deviation & 3 & 0 \\
Right axis deviation & 2 & 0 \\
Clockwise cardiac rotation & 2 & 2 \\
\hline
\end{tabular}

TABLE 5 Sequential changes in group 1

\begin{tabular}{|c|c|c|c|c|}
\hline \multicolumn{2}{|c|}{$\begin{array}{l}\text { Case } \\
\text { No. }\end{array}$} & \multirow{2}{*}{$\begin{array}{l}T \text { wave } \\
\begin{array}{l}\text { +ve } \\
\text { +ve }\end{array}\end{array}$} & \multirow{2}{*}{$\begin{array}{l}\text { Frontal } \\
\text {-ve }\end{array}$} & \multirow{2}{*}{$\begin{array}{l}\text { QRS } \\
\text { Transverse } \\
\text {-ve }\end{array}$} \\
\hline 2 & $\begin{array}{r}12 \\
3\end{array}$ & & & \\
\hline 3 & $\begin{array}{r}12 \\
3\end{array}$ & $\begin{array}{l}\text { +ve } \\
\text { +ve }\end{array}$ & $-\mathrm{ve}$ & -ve \\
\hline 9 & $\begin{array}{r}12 \\
3\end{array}$ & $\begin{array}{l}\text { - ve } \\
\text { +ve }\end{array}$ & -ve & -ve \\
\hline 10 & $\begin{array}{r}12 \\
3\end{array}$ & $\begin{array}{l}\text { +ve } \\
\text { +ve }\end{array}$ & $-v e$ & -ve \\
\hline 11 & $\begin{array}{r}12 \\
3\end{array}$ & $\begin{array}{l}\text {-ve } \\
\text { +ve }\end{array}$ & -ve & -ve \\
\hline 12 & $\begin{array}{r}12 \\
3\end{array}$ & $\begin{array}{l}\text {-ve } \\
\text {-ve }\end{array}$ & $8 \rightarrow 26 \rightarrow 72$ & $331 \rightarrow 291 \rightarrow 340$ \\
\hline 13 & $\begin{array}{r}12 \\
3\end{array}$ & $\begin{array}{l}\text { +ve } \\
\text { +ve }\end{array}$ & $268 \rightarrow 190$ & $262 \rightarrow 209$ \\
\hline 14 & $\begin{array}{r}12 \\
3\end{array}$ & $\begin{array}{l}\text { +ve } \\
\text { +ve }\end{array}$ & $182 \rightarrow 163 \rightarrow 136$ & $223 \rightarrow 225 \rightarrow 237$ \\
\hline
\end{tabular}

significant $Q R S$ or $T$ vector changes on the 3 lead electrocardiogram whereas in only one patient were sequential changes noted by the 12 lead electrocardiogram. Two patients in this group had no pulmonary hypertension, 2 had moderate pulmonary hypertension, and the remaining 2 had severe pulmonary hypertension.

\section{Discussion}

Twelve lead electrocardiographic appearances after acute pulmonary embolism have been well documented. Few of these are diagnostic of pulmonary embolism though the $S_{1} Q_{3} T_{3}$ pattern (McGinn and White, 1935) and $T$ wave inversion in the right praecordial leads (Sutton, Honey, and Gibson, 1969) are helpful confirmatory findings. The former is more likely to be present when there is major pulmonary vascular obstruction with pulmonary hypertension but even then this abnormality may not occur (McIntyre, Sasahara, and Littmann, 1972), and the latter appears to be particularly associated with acute massive pulmonary embolism (Sutton et al., 1969). In the 3 patients in this study with $S_{1} Q_{3} T_{3}$, the 3 lead electrocardiogram did not show a specific abnormality with which this pattern could be equated but nevertheless showed striking right axis deviation in two, with a $Q_{y} S_{x}$ pattern in the third. In respect of 5 of 20 patients with $T$ wave abnormalities in the right praecordial leads V1 to V3, the computer interpretation of the 3 lead electrocardiogram also noted anteroseptal $\mathrm{T}$ wave abnormalities and commented on their relevance to the clinical diagnosis of pulmonary embolism. Three of these patients had significant haemodynamic changes, one had 
TABLE 6 Electrocardiographic findings in group 2

\begin{tabular}{|c|c|c|c|c|c|c|c|c|}
\hline \multicolumn{2}{|c|}{$\begin{array}{l}\text { Case } \\
\text { No. }\end{array}$} & \multirow{2}{*}{$\begin{array}{l}\text { Initial } \\
\text { Atrial fibrillation }\end{array}$} & $\begin{array}{l}\text { Seq } \\
T \amalg\end{array}$ & $\begin{array}{l}\text { uential } \\
\text { Vave }\end{array}$ & $\begin{array}{l}\text { anges } \\
\text { QRS } \\
\text { Frcntal }\end{array}$ & Transverse & \multicolumn{2}{|c|}{$\begin{array}{l}\text { Pulmonary artery } \\
\text { pressure }\end{array}$} \\
\hline 15 & $\left.\begin{array}{r}3 \\
12\end{array}\right\}$ & & $\begin{array}{r}3 \\
12\end{array}$ & $\begin{array}{l}\text { +ve } \\
\text {-ve }\end{array}$ & $\begin{array}{l}18 \rightarrow 7 \rightarrow 48 \\
-v e\end{array}$ & $\begin{array}{l}324 \rightarrow 294 \rightarrow 274 \\
-v e\end{array}$ & $25 / 18$ & $3 \cdot 3 / 2 \cdot 4$ \\
\hline 16 & $\left.\begin{array}{r}3 \\
12\end{array}\right\}$ & $\begin{array}{l}\text { Sinus rhythm; LAD } \\
\text { Anteroseptal myocardial infarction }\end{array}$ & $\begin{array}{r}3 \\
12\end{array}$ & $\begin{array}{l}\text {-ve } \\
\text {-ve }\end{array}$ & $\begin{array}{l}\text {-ve } \\
\text {-ve }\end{array}$ & $\begin{array}{l}\text {-ve } \\
\text {-ve }\end{array}$ & $43 / 23$ & $5 \cdot 7 / 3 \cdot 1$ \\
\hline 17 & $\begin{array}{l}3\} \\
12\}\end{array}$ & $\begin{array}{l}\text { Sinus rhythm, LAD } \\
\text { Inferior myocardial infarction }\end{array}$ & 12 & $\begin{array}{l}\text { tve } \\
\text { - ve }\end{array}$ & $\begin{array}{l}\text {-ve } \\
\text {-ve }\end{array}$ & $\begin{array}{l}\text {-ve } \\
\text {-ve }\end{array}$ & $24 / 10$ & $3 \cdot 2 / 1 \cdot 3$ \\
\hline 18 & $\left.\begin{array}{r}3 \\
12\end{array}\right\}$ & $\begin{array}{l}\text { Sinus rhythm } \\
\text { Widespread myocardial ischaenia }\end{array}$ & $\begin{array}{r}3 \\
12\end{array}$ & $\begin{array}{l}\text { +ve } \\
\text {-ve }\end{array}$ & $\begin{array}{l}\text {-ve } \\
\text {-ve }\end{array}$ & $\begin{array}{l}\text {-ve } \\
\text {-ve }\end{array}$ & $45 / 17$ & $6 \cdot 0 / 2 \cdot 3$ \\
\hline 19 & $\begin{array}{r}3 \\
12\end{array}$ & $\begin{array}{l}\text { Sinus rhythm } \\
\mathrm{T} \text { wave inversion in anteroseptal leads }\end{array}$ & $\begin{array}{r}3 \\
12\end{array}$ & $\begin{array}{l}\text { +ve } \\
\text { +ve }\end{array}$ & $\begin{array}{l}47 \rightarrow 70 \rightarrow 58 \\
- \text { ve }\end{array}$ & $\begin{array}{l}344 \rightarrow 304 \rightarrow 337 \\
\text {-ve }\end{array}$ & $66 / 26$ & $8 \cdot 8 / 3.5$ \\
\hline 20 & $\left.\begin{array}{r}3 \\
12\end{array}\right\}$ & $\begin{array}{l}\text { Atrial fibrillation; RAD } \\
\text { Clockwise cardiac rotation }\end{array}$ & $\begin{array}{r}3 \\
12\end{array}$ & $\begin{array}{l}\text { - ve } \\
\text { - ve }\end{array}$ & $\begin{array}{l}156 \rightarrow 119 \rightarrow 76 \\
-v e\end{array}$ & $\begin{array}{l}178 \rightarrow 239 \rightarrow 231 \\
-v e\end{array}$ & $84 / 55$ & $11 \cdot 2 / 7 \cdot 3$ \\
\hline
\end{tabular}

moderately raised pulmonary artery pressure and one had normal pressure. Sequential $T$ wave changes in group 1 were detected in 7 patients by the 3 lead electrocardiogram and in 5 patients by the 12 lead electrocardiogram. In group 2, it was extremely difficult to infer any relation between $T$ wave changes and acute pulmonary embolism, but 3 out of 6 patients showed sequential $T$ vector changes in the 3 lead electrocardiogram whereas no sequential $T$ wave changes were evident on the 12 lead electrocardiogram.

The diagnosis of QRS axis shifts can be accurately estimated in the 3 lead system and an abnormality of the frontal or transverse maximum QRS vector occurred at some stage in 11 of 20 $(55 \%)$ patients. All patients with initial right axis deviation showed subsequent abnormal $Q R S$ vector shifts and a further 3 showed significant sequential QRS vector shifts. Left axis deviation was noted on at least one occasion in 5 of $20(25 \%)$ patients, in keeping with the findings of Lynch, Stein, and Bruce (1972) who reported that left axis deviation was twice as common as right axis deviation in patients with acute pulmonary embolism.

Clockwise cardiac rotation is known to be associated with acute pulmonary embolism (Cutforth and Oram, 1958; Phillips and Levine, 1950). All of the 3 patients with clockwise cardiac rotation in our series retained this abnormality throughout the period of the study, though the $Q R S_{\mathrm{T}}$ vector rotated clockwise while the $Q R S_{F}$ vector correspondingly rotated in an anticlockwise direction as the time from the initial incident increased.

The temporal relation of electrocardiographic changes and acute pulmonary embolism is of great importance, and Spodick (1972) has emphasized the value of establishing a relation between likely time of the acute embolism and the initial electrocardio- gram. In this study 13 patients $(65 \%)$ had tracings recorded within 24 hours of initial symptoms while the remaining 7 patients had their first electrocardiogram recorded within 48 hours.

There was no specific 3 orthogonal lead electrocardiographic pattern which could be said to be typical of pulmonary embolism. Classical signs such as $T$ wave inversion in the anteroseptal lead appeared simultaneously in both lead systems but could not be regarded as pathognomonic of pulmonary embolism. Likewise while significant QRS vector shifts outside normal day-to-day variation occurred in 6 of $20(30 \%)$ patients, there was no pattern to suggest that one direction of rotation was prevalent. This is in keeping with findings of right and left axis deviation in patients with pulmonary embolism. Thus, there was no diagnostic criterion which could be regarded as a definite indication of pulmonary embolism.

Although there are additional difficulties in the assessment of electrocardiographic changes in patients with previously abnormal tracings, the exact effect of previous cardiopulmonary disease is not certain. It has been suggested, both in animals (Just-Viera et al., 1965) and in man (Szucs et al., 1971), that the incidence of electrocardiographic abnormalities may not be altered. It seems that the important factor in this situation is the demonstration of a changing electrocardiogram in the presence of a known pre-existing abnormality. We have found that in 5 out of 6 patients with known cardiac or respiratory disease, sequential 3 lead electrocardiographic changes occurred. In only one patient were definite sequential changes noted on the 12 lead tracings. These findings suggest that serial 3 lead tracings in this type of patient with suspected pulmonary embolism are of more value in supporting the diagnosis than the 12 lead electrocardiogram. 


\section{References}

Cawood, H. T., Macfarlane, P. W., Hillis, S., and Lawrie, T. D. V. (1974). Day to day and beat to beat variation in normal 3 orthogonal lead electrocardiograms. British Heart fournal, 36, 1225.

Cutforth, R. H., and Oram, S. (1958). The electrocardiogram in pulmonary embolism. British Heart fournal, 20, 41.

Goldman, M. J. (1970). Principles of Clinical Electrocardiography, 7th ed. Blackwell, Oxford.

Just-Viera, J. O., Hashimoto, S., Gonzalez, L. F., and Yeager, G. H. (1965). Massive pulmonary embolism V. Evolution of electrocardiographic and enzyme changes in survivors. Archives of Surgery, 91, 497.

Lynch, R. E., Stein, P. D., and Bruce, T. A. (1972). Leftward shift of frontal plane $Q R S$ axis as a frequent manifestation of acute pulmonary embolism. Chest, 61, 443.

Macfarlane, P. W. (1969). A modified axial lead system for orthogonal lead electrocardiography. Cardiovascular $R e$ search, 3, 510 .

Macfarlane, P. W., Cawood, H. T., and Lawrie, T. D. V. (1975). A basis for computer interpretation of serial electrocardiograms. Ccmputers and Biomedical Research, 8, 189.

Macfarlane, P. W., and Lawrie, T. D. V. (1974). An Introduction to Automated Electrocardiogram Interpretation. Butterworths, London.

Macfarlane, P. W., and Lawrie, T. D. V. (1977). Three Lead Electrocardiography. Butterworths, London. In the press.
McGinn, S., and White, P. D. (1953). Acute cor pulmonale resulting from pulmonary embolism. Fournal of the American Medical Association, 104, 1473.

McIntyre, K. M., Sasahara, A. A., and Littmann, D. (1972). Relation of the electrocardiogram to hemodynamic alterations in pulmonary embolism. American fournal of Cardiology, 30, 205.

Phillips, E., and Levine, H. D. (1950). A critical evaluation of extremity and precordial electrocardiography in acute cor pulmonale. American Heart fournal, 39, 205.

Spodick, D. H. (1972). Electrocardiographic responses to pulmonary embolism. American fournal of Cardiology, 30, 695.

Stein, P. D., Dalen, J. E., McIntyre, K. M., Sasahara, A. A., Wenger, N. K., and Willis, P. W. (1975). The electrocardiogram in acute pulmonary embolism. Progress in Cardiovascular Diseases, 17, 247.

Sutton, G. C., Honey, M., and Gibson, R. V. (1969). Clinical diagnosis of acute massive pulmonary embolism. Lancet, $1,271$.

Szucs, M. M., Brooks, H. L., Grossman, W., Banas, J. S., Meister, S. G., Dexter, L., and Dalen, J. E. (1971). Diagnostic sensitivity of laboratory findings in acute pulmonary embolism. Annals of Internal Medicine, 74, 161.

Requests for reprints to Dr. P. W. Macfarlane, University Department of Medical Cardiology, Royal Infirmary, Glasgow G4 OSF. 